\title{
Difficulties in adaptation to climate change by farmers in Enugu State, Nigeria
}

\author{
Nicholas Ozor ${ }^{1}$ and Nnaji Cynthia ${ }^{2}$ \\ ${ }^{1}$ Post Doctoral Research Officer \\ African Technology Policy Studies Network (ATPS) \\ $3^{\text {rd }}$ Floor, The Chancery, Valley Road \\ P. O. Box 10081-00100 \\ Nairobi, Kenya \\ Emails: nozor@atpsnet.org; nicholas.ozor@unn.edu.ng \\ Mobile: +254713161928 \\ ${ }^{2}$ Department of Agricultural Extension \\ Faculty of Agriculture \\ University of Nigeria, Nsukka, Enugu State, Nigeria \\ Email: cynthynice@yahoo.com \\ Mobile: +2348039462574
}

\begin{abstract}
The impacts of global climate change on agricultural production and food security are serious source of worry to farmers in sub-Saharan Africa. This is because their economies mainly depend on agriculture which is now affected by climate change catastrophes. The paper examines why farmers find it difficult to adapt to climate change impacts. A multi-stage random sampling technique was used in selecting 120 farmers that participated in the study. Both descriptive and inferential statistics were used in analyzing data. Major results show that the most difficult challenges faced by farmers in adapting to climate change impacts in the State were: lack of improved agricultural technologies, low adaptive capacities, and unsustainable agricultural practices. Furthermore, a framework for climate change adaptation shows that a mix of agronomic best practices, technology and innovation development and institutional and policy reforms were proposed as capable of improving farmers' adaptation capacity to climate change. The paper concluded with the recommendation that farmers' adaptation capacities to climate change need to be urgently strengthened by extension service so as to sustain agricultural production and food security even in the event of climate change.
\end{abstract}

Key words: Farmers, Climate change, Agriculture, Adaptation, Extension, Enugu State

${ }^{1}$ Corresponding author 


\section{INTRODUCTION}

It is quite obvious that the ever increasing levels of greenhouse gas emissions, which cause global warming, have the biggest impact on agriculture. Agriculture, particularly in the developing countries, depends so much on weather and natural soil conditions. Incidentally, over $75 \%$ of agricultural production takes place in rural areas where more than $80 \%$ are engaged in farming activities. Farmers in these areas unfortunately lack the basic infrastructure and modern technology to engage in any meaningful production, hence they are subsistent and fully depend on natural climate as a determinant for planting, weeding, fertilizing, harvesting and carrying out other operations in the value chain. The current catastrophic incidences of climate change recorded the world over present new challenges to agricultural production in developing countries and particularly in sub-Saharan Africa. Already, the Intergovernmental Panel on Climate Change (IPCC) had predicted that Africa is the most vulnerable to climate change impacts (IPCC, 2007). Uncertainties in weather patterns, rainfall, drought and flooding events have meant that rural farmers who implement their regular annual farm business plan risk total crop/livestock failure due to climate change effects.

The agricultural sector was prioritized as most critical under the current climate change scenarios as it will have direct impacts on rural livelihoods and also as agriculture is the mainstay of most African national economies. In addition to dependence of many of the economies on rain-fed agriculture, a consultation exercise carried out by the African Technology Policy Studies Network (ATPS) and the United Nations Environment Programme (UNEP) facilitated Global Adaptation Network (GAN) (2008) revealed that factors such as increased intensity, frequencies, prevalence and uncertain patterns of land degradation, pests and diseases, droughts, flooding events, and most importantly low technical and innovation capacity to adapt to climate change are the most significant indicators of farmers' ability to implement, create, alter, and implement multiple mitigation and adaptation measures.

Impacts of climate change on agriculture are different and diverse depending on many factors such as time, location, and response strategies (mitigation and adaptation) put in place. Changes in crop development and phonology for instance can cause shortening or lengthening of crop cycles that could lead to decrease or increase in productivity. Structural changes, especially in carbohydrate status of plants can also occur. This may affect the nutritional value, taste and storage quality of some fruits and vegetables. Significant reduction of rainfall in the SudanSahel belt would make the region drier, with consequent reduction in crop productivity. Decreased rainfall in the region would also reduce the primary productivity of the grassland areas in which livestock production is currently important.

The livestock production systems would be vulnerable to climate change in respect of anticipated decrease in rainfall in Sudan-Sahelian zones and consequent reduction in the available pastureland; declining availability of surface water resources for animals; possible increase in salinity at water resources for animals; and possible increase in salinity at watering points due to increase in 
temperature and evaporation in the face of reduced rainfall. Climate change leads to decrease in livestock production, resulting in an impaired availability of animal protein, including meat, egg, milk and animal products such as hides and skins. These have implications for food security. Subtle changes in key environmental variables such as temperature, salinity, wind speed and direction, ocean currents, strength of upwelling due to climate change could sharply alter the abundance, distribution and availability of fish population (African Action, 2007).

Indirect effects of climate change on agriculture include effects on pests and diseases and the impacts of these on agricultural production. It is thought that various pests including the tobacco cut worm, rice sting bug, rice weevil and soybean pod borer would probably expand their distribution areas in the events of climate change. Also, an increase in the frequency of extreme events such as prolonged drought or intense flooding could create conditions that could be conducive to disease or pest outbreaks and severely disrupt the predator-prey relationships that normally restrict the proliferation of pests (Ozor, 2009).

The implication of these scenarios for the attainment of the Millennium Development Goals (MDGs) is obvious, especially in developing countries where systems resilience is low. These situations call for development interventions that will jointly boost the resilience of vulnerable people at the local, regional and international levels so as to reduce the incidences of climate change risks on agriculture. The best way to ensure adaptability is to increase resilience or the capacity to cope with natural year-to-year climate variability such as flood or drought years as noted by Pittock (2005).

Therefore, mitigation and adaptation remain the most popular options to manage the impacts of climate change on agriculture in the world today. However, while neither adaptation nor mitigation actions alone can prevent significant climate change impacts, taken together, they can significantly reduce food security risks. While mitigation is necessary to reduce the rate and magnitude of climate change, adaptation is essential to reduce the damages from climate change that cannot be avoided.

The pertinent questions to ask therefore are: Are farmers in rural areas capable of adapting to the impacts of climate change? If not, why do they find it difficult to adapt? How can they then adapt to these climate change challenges in order to sustain their agricultural production? This paper focuses on providing answers to these questions.

\section{Purpose and objectives}

The overall purpose of the study was to examine why farmers in Enugu State find it difficult to adapt to the impacts of climate change on their agricultural activities. The specific objectives were to:

1. characterize the farmers in the study area;

2. identify problems that farmers encounter in adapting to the impacts of climate change on agriculture; and 
3. develop a framework for mitigating and adapting to the impacts of climate change on agriculture.

\section{Theoretical considerations}

Climate change refers to change in climate, which is attributed directly or indirectly to human activities that alter the composition of the global atmosphere, and which are in addition to natural variability observed over comparable time periods (Intergovernmental Panel on Climate Change (IPCC), 2007). Global climate change poses an unprecedented challenge to humanity's skill at maintaining viable livelihoods under highly diverse and variable climatic and environmental conditions (Consultative Group on International Agricultural Research (CGIAR), 2008). There have been observed changes in climate parameters including cloud cover, precipitation, diurnal temperature range, minimum temperature, maximum temperature, average daily temperature and vapor pressure which is attributed to greenhouse gas increases in the atmosphere.

Gases that trap heat in the atmosphere are often referred to as greenhouse gases. Greenhouse gases are the primary cause of global warming (Food and Agriculture Organization, FAO, 2007). Increased concentrations of greenhouse gases in the atmosphere enhance the potential of the atmosphere to conserve heat and therefore bring about global warming. Global warming is the fundamental element in anthropogenic climate change (Ministry of Environment of the Federal Republic of Nigeria, 2003). The major greenhouse gases include carbon (IV) carbon $\left(\mathrm{CO}_{2}\right)$, nitrous oxide $\left(\mathrm{N}_{2} \mathrm{O}\right)$ and methane $\left(\mathrm{CH}_{4}\right)$. These gases enter the earth's atmosphere through human activities. They collectively shape the atmosphere and this has its major effects on agro ecosystem.

Climate change no doubt compounds the serious problems of sustainability of the environment and management of resources as well as the currently serious problems in population and consumption patterns and characteristics in Nigeria (Ministry of Environment of the Federal Republic of Nigeria, 2003). According to the ministry, there are serious consequences of climate change on agriculture, livestock production and management, health, ecosystems, forests and forestry, fisheries and other economic activities. This no doubt has serious impact on national development.

Climate change is a reality and thus calls for mainstreaming of necessary measures aimed at adapting to or mitigating the threat posed by it. While mitigation refers to measures to prevent or slow greenhouse gas emissions that lead to global warming, adaptation refers to actions, strategies, practices and mechanisms, which reduce vulnerability to climate change impacts (IPCC, 2001). The two main types of adaptation are autonomous and planned adaptation. Autonomous adaptation is the reaction of, for example, a farmer to changing precipitation patterns, in that he/she changes crops, uses different harvest and planting/sowing dates. Planned adaptation measures are conscious policy options or response strategies, often multi-sectoral in nature and aimed at altering the adaptive capacity of the agricultural system or facilitating specific adaptations. For 
example, elaborate crop selection and distribution strategies across different agroclimatic zones, substitution induced by scarcity, etc FAO, (2007).

In addition to autonomous adaptation of ecosystem to the effects of climate change, there must be planned adaptation and adoption of adaptation strategies in order to minimize the negative impact of climate change on the ecosystem, water resources, socio-economic domain and the agricultural sector if sustainability is to be ensured. Adaptation to climate change according to other schools of thoughts is any activity that reduces the negative impacts of climate change and/or takes advantage of new opportunities that may be presented (Natural Resources Canada, NRC, 2008). It includes activities that are taken before impacts are observed (anticipatory) and after impacts have been felt (reactive). Both anticipatory and reactive adaptation can be planned (i.e. the result of deliberate policy decisions), and reactive adaptation can also occur spontaneously. In most circumstances, anticipatory planned adaptations will incur lower long-term costs and be more effective than reactive adaptations.

An assessment of adaptation options is very important. It involves the identification and evaluation of possible options or changes in policies, practices and technologies as well as actions designed to adapt to or to take advantage of new opportunities that may arise as a result of climate change (Ministry of Environment of the Federal Republic of Nigeria, 2003). It is important to assess different adaptation options in terms of availability, benefits, costs, effectiveness, efficiency and feasibility. In view of these, a major problem is that of identifying the most appropriate adaptation option for different crop and animal production options for specific regions. More importantly, it is imperative to examine obstacles that hinder farmers from adapting to the impacts of climate change. This way, it will be easy to address them proactively.

\section{METHODOLOGY}

The study was carried out in Enugu State of Nigeria. Enugu State is one of the 36 states in Nigeria and is located between latitude $5^{\circ} 56^{\prime} \mathrm{N}$ and $7^{\circ} 06^{\prime} \mathrm{N}$ and longitude $6^{\circ} 53^{\prime} \mathrm{E}$ and $7^{\circ} 55^{\prime} \mathrm{E}$ (Ezike, 1998). The State has a population of 2,452,996 (National Population Commission, NPC, 2006). The vegetation of the state is mainly forest type but stretches out into derived Savannah in the north fringes. Enugu State experiences distinct wet and dry seasons with a total annual rainfall of about 1,700mm (Enugu State Government Official Gazette, No. 25, 1997). The major occupation of people in the state is farming. Major crops cultivated include, cassava, yam, cocoyam, vegetables, oil palm etc, while major livestock reared are poultry, goat, sheep and cattle.

The State has seventeen local government areas (LGAs) and is divided into three agricultural zones namely:

1) Enugu North Zone, comprising Igbo-Etiti, Uzo Uwani, Nsukka, Udenu, IgboEze North and Igbo-Eze South LGAs;

2) Enugu East Zone, comprising Nkanu West, Nkanu East, Enugu North, Enugu South, Enugu East and Isi Uzo LGAs; 
3) Enugu West Zone comprising Udi, Ezeagu, Oji River, Awgu and Aninri LGAs (ENADEP, 2007).

Farmers in the State constituted the population for the study. A multi-stage random sampling technique was used to select respondents. Two agricultural zones (Enugu North and Enugu West) were randomly selected. Two LGAs were randomly selected from each of the two zones. For Enugu North Zone, Nsukka and Udenu LGAs were randomly selected while Udi and Oji River LGAs were selected from Enugu West Zone. Two town communities were also randomly selected from each LGA to give a total of eight town communities. They include Ibagwa-Ani and Okpuje (Nsukka), Obollo Eke and Amala (Udenu), Agbala-Enyi and Ugwuoba (Oji River), and Awhum and Nsude (Udi). Fifteen farmers with long years of farm experience were purposively selected from each of the town community. The preference for farmers with long years of farm experience was made so as to gain the most useful information from them on their experiences of changes in climate as it affects their farming practices and production. This gave a sample size of 120 .

Data for the study were collected through a semi-structured interview schedule that was validated by experts in agricultural extension and climatology. Secondary data were also used to complement the primary data sources. A focus group discussion (FGD) was held in each zone to obtain more in-depth information from farmers on the subject matter. A pilot test was also conducted as part of the instrument validation and to test for reliability. Data were collected between June 2008 and October 2008.

In order to characterize the respondents, issues on their socio economic characteristics such as headship of household, age, marital status, size of household, level of education, degree obtained, occupation (major and minor), years of experience in farming and systems of farming, were ascertained. In identifying the difficulties farmers face in adapting to the impacts of climate change, in-depth literature reviews, expert opinions and observations were utilized in framing the questions used. A four point Likert-type scale with options of strongly agree (SA), agree (A), disagree (D), and strongly disagree (SD) with nominal values of $4,3,2$ and 1 respectively was used to obtain responses from farmers. Also, to develop the framework for adaptation and mitigation to climate change, various mitigation and adaptation options obtained from literature, expert opinions and observations were equally utilized. Farmers were asked to tick options they apply in their farming systems which they consider very effective. Measures that scored $50 \%$ and above were used in the development of the framework for mitigation and adaptation to climate change impacts.

Data were analyzed using both descriptive and inferential statistics. Objective one was analyzed using frequency and mean scores, objective two was analyzed using factor analysis with varimax rotation, while objective three was analyzed using ranking procedure. The factor loading under each constraint (beta weight) represent a correlation of the variables (constraint areas) to the identified constraint factor and has the same interpretation as any correlation coefficient. However, only variables with loadings of 0.40 and above (10\% overlapping 
variance) (Comrey, 1962) were considered in naming the factors. All significance were tested at $5 \%$ level of probability.

\section{RESULTS AND DISCUSSIONS}

\section{Selected socio economic characteristics of respondents}

Results in Table 1 show that majority (58.9\%) of the respondents were males while $41.1 \%$ were females. This indicates that there were more male-headed households engaged in farming than female-headed households in the study area. The finding agrees with that of Achike (2002) who found out that more males were involved in farming than women in Enugu State. Results also reveal that (32.6\%) of the respondents were between the age bracket of 41 and 50 years. This shows that they are still young with moderate experience in farming and can still actively adopt effective measures for cushioning the impacts of climate change. 
TABLE 1: Socio-economic characteristics of respondents $(n=120)$

\begin{tabular}{|c|c|c|}
\hline Variables & Frequency & Percentage \\
\hline $\begin{array}{l}\text { Household head } \\
\text { Male } \\
\text { Female }\end{array}$ & $\begin{array}{l}53 \\
37\end{array}$ & $\begin{array}{l}58.9 \\
41.1\end{array}$ \\
\hline \multicolumn{3}{|l|}{ Age } \\
\hline Below 20 years & 5 & 5.6 \\
\hline $21-30$ years & 12 & 13.5 \\
\hline $31-40$ years & 24 & 27.0 \\
\hline $41-50$ years & 29 & 32.6 \\
\hline $51-60$ years & 16 & 18.0 \\
\hline \multirow{2}{*}{\multicolumn{3}{|c|}{ Marital status }} \\
\hline & & \\
\hline Singe & 15 & 17.2 \\
\hline Married & 59 & 67.8 \\
\hline Divorced & 2 & 2.3 \\
\hline Widowed/widower & 11 & 12.6 \\
\hline \multicolumn{3}{|l|}{ Level of education } \\
\hline No formal education & 9 & 10.1 \\
\hline Primary education & 8 & 9.0 \\
\hline Secondary education & 17 & 19.1 \\
\hline Tertiary education & 55 & 61.8 \\
\hline \multicolumn{3}{|l|}{ Deqree obtained } \\
\hline OND & 5 & 9.6 \\
\hline NCE & 2 & 3.8 \\
\hline HND & 7 & 13.5 \\
\hline B.Sc & 33 & 63.5 \\
\hline M.Sc. & 4 & 7.7 \\
\hline $\mathrm{PhD}$ & 1 & 1.9 \\
\hline \multicolumn{3}{|l|}{ Size of household } \\
\hline $1-5$ & 52 & 5.1 \\
\hline \multicolumn{3}{|l|}{ Major occupation } \\
\hline Farming & 67 & 80.7 \\
\hline Trading & 1 & 1.2 \\
\hline Civil service & 15 & 18.1 \\
\hline \multicolumn{3}{|l|}{ Minor occupation } \\
\hline Farming & 22 & 26.5 \\
\hline Training & 49 & 49.0 \\
\hline Civil service & 7 & 8.4 \\
\hline Teaching & 2 & 2.4 \\
\hline Palm wine tapping & 2 & 2.4 \\
\hline Motor mechanic & 1 & 1.2 \\
\hline \multicolumn{3}{|l|}{ Years of farming experience } \\
\hline$<5$ years & 15 & 16.9 \\
\hline $5-10$ years & 24 & 27.0 \\
\hline $11-15$ years & 27 & 30.3 \\
\hline $16-20$ years & 16 & 18.0 \\
\hline 20 and above & 7 & 7.9 \\
\hline \multicolumn{3}{|l|}{ System of farming } \\
\hline Crop only & 20 & 23.3 \\
\hline Livestock only & 10 & 11.6 \\
\hline Crop and livestock & 51 & 54.3 \\
\hline Crop, livestock and fishery & 5 & 5.8 \\
\hline
\end{tabular}

Data in Table 1 also reveal that majority (67.8\%) of the respondents were married. This shows that the gender roles in agricultural production and climate change adaptation can be effectively distributed among the men and women. In his 
findings, Ekwueme (2006) noted that $73.3 \%$ of cassava farmers in Enugu State were married. Further results in Table 1 show that majority $(61.8 \%)$ of the respondents had tertiary education of whom $63.5 \%$ had B.Sc university certificates. This indicates that most of the farmers in Enugu State were literate and can take effective steps towards adaptation options. It has been reported by Agwu and Anyanwu (1996), that increase in educational status of farmers positively influence adoption of improved technologies and practices. Again, Table 1 shows that majority (57.2\%) of the respondents had family sizes of between 1 and 5 persons in their household. The average household size was 5 members. This finding indicates a fairly large family size. The implication of this is that more family labour will be readily available since relatively large household size has been reported by lgben (1988) to be an obvious advantage in terms of farm labour supply.

It is also revealed in Table 1 that majority (80.7\%) of the respondents had farming as their major occupation and hence is capable of giving information regarding the impacts of climate change on agriculture, the adaptation options adopted and the difficulties in adaptation. The table further showed that $59.0 \%$ of the respondents engaged in trading as a secondary occupation. They do this to provide a kind of social and economic insurance to crop failures that can result from the impacts of climate change and other factors. Table 1 also shows that a greater proportion $(30.3 \%)$ of the respondents had between 11-15 years of farming experience. This indicate that majority of the respondents had long time farming experience and could have over the years experienced changes in the climate in the area. They may have acquired wealth of knowledge on the indigenous adaptive measures for cushioning the effects of climate change as well as identified obstacles for effective adaptation. Mapuno et al (2008) earlier noted that farmers could be in a better position to identify challenges and opportunities on climate change. Finally, results in Table 1 revealed that more than half $(54.3 \%)$ of the respondents engaged in both crop and livestock enterprises together. This implies that farmers actually will be vulnerable to climate change impacts as crop and livestock form the main categories affected by the change.

\section{Difficulties in adaptation to climate change impacts}

Results in Table 2 show the difficulties farmers encounter in adapting to climate change impacts in Enugu State. Based on the item loadings of the factor analysis conducted, three critical factors were isolated and named: lack of improved agricultural technologies (Factor 1), low adaptive capacity (Factor 2), and unsustainable agricultural practices (Factor 3 ). The three factors therefore represent the major difficulties that farmers encounter in adapting to climate change impacts in Enugu State.

Specifically, the items that loaded high under Factor 1 (lack of improved agricultural technologies) include: lack of improved varieties of crops that yield more in the event of climate change (0.92), lack of improved varieties of crop that are pest and disease resistant (0.89), lack of crop varieties that are adaptable to low rainfall (0.90), lack of crop varieties that are resistant to drought (0.67), ineffectiveness of cover crops and mulches in preventing weed growth (0.65), 
drudgery associated with farming (0.60), poor water harvesting technologies (0.56), and lack of weather forecasting technologies (0.76).

Items that amplified low adaptive capacity (Factor 2) include: inadequate protection from moisture losses by cover crops due to heat stress (0.67), inadequate finance to cope with the changing climate (0.73), lack of effective advice on coping strategies (0.66), illiteracy and lack of knowledge on adaptation (0.62), inadequate organic manure for improving the soil structure (0.54), lack of functional irrigation schemes (0.73), lack of and high cost of fertilizers (0.76), and untimely supply of essential farm inputs (0.76).

Similarly, the items that loaded high under Factor 3 (Unsustainable agricultural practices) include: loss in crop yields due to improper tillage (0.76), intense weed growth due to minimum tillage operation (0.64), pest and diseases infestation due to minimum tillage operation (0.66), caking of the soil surface due to improper tillage that increases erosion menace (0.57), smothering of crops planted early due to heat stress (0.87), and wild fire incidences on farms $(0.60)$. 
TABLE 2: Factor analysis showing the difficulties faced by farmers in adapting to climate change impacts

\begin{tabular}{|c|c|c|c|c|}
\hline & Constraints & \multicolumn{3}{|c|}{ Factors $^{\star}$} \\
\hline 1 & $\begin{array}{l}\text { Lack of improved varieties of crops that yield } \\
\text { more in the event of climate change }\end{array}$ & $\begin{array}{c}1 \\
0.92\end{array}$ & -0.09 & $\begin{array}{c}3 \\
0.07\end{array}$ \\
\hline 2 & $\begin{array}{l}\text { Lack of improved varieties of crop that are pest } \\
\text { and disease resistant }\end{array}$ & 0.89 & -0.04 & 0.00 \\
\hline 3 & $\begin{array}{l}\text { Lack of crop varieties that are adaptable to low } \\
\text { rainfall }\end{array}$ & 0.90 & -0.15 & -0.16 \\
\hline 4 & $\begin{array}{l}\text { Lack of crop varieties that are resistant to } \\
\text { drought }\end{array}$ & 0.67 & 0.17 & 0.27 \\
\hline 5 & Loss in crop yields due to improper tillage & 0.06 & 0.40 & 0.76 \\
\hline 6 & $\begin{array}{l}\text { Intense weed growth due to minimum tillage } \\
\text { operation }\end{array}$ & 0.21 & 0.26 & 0.64 \\
\hline 7 & $\begin{array}{l}\text { Pest and diseases infestation due to minimum } \\
\text { tillage operation }\end{array}$ & 0.28 & 0.26 & 0.66 \\
\hline 8 & $\begin{array}{l}\text { Poor yield from root and tuber crops due to } \\
\text { improper soil tillage operations }\end{array}$ & 0.67 & 0.27 & 0.28 \\
\hline 9 & $\begin{array}{l}\text { Caking of the soil surface due to improper tillage } \\
\text { that increases erosion menace }\end{array}$ & -0.03 & 0.30 & 0.57 \\
\hline 10 & $\begin{array}{l}\text { Smothering of crops planted early due to heat } \\
\text { stress }\end{array}$ & -0.02 & 0.23 & 0.87 \\
\hline 11 & $\begin{array}{l}\text { Inadequate protection from moisture losses by } \\
\text { cover crops due to heat stress }\end{array}$ & 0.04 & 0.67 & 0.03 \\
\hline 12 & $\begin{array}{l}\text { Inadequate finance to cope with the changing } \\
\text { climate }\end{array}$ & 0.29 & 0.73 & 0.28 \\
\hline 13 & Lack of effective advice on coping strategies & 0.37 & 0.66 & 0.11 \\
\hline 14 & Illiteracy and lack of knowledge on adaptation & 0.23 & 0.62 & 0.38 \\
\hline 15 & $\begin{array}{l}\text { Inadequate organic manure to be used for } \\
\text { improving the soil structure }\end{array}$ & 0.04 & 0.54 & 0.37 \\
\hline 16 & $\begin{array}{l}\text { Ineffectiveness of cover crops and mulches in } \\
\text { preventing weed growth }\end{array}$ & 0.65 & -0.15 & 0.18 \\
\hline 17 & Wild fire incidences on farms & 0.06 & 0.13 & 0.60 \\
\hline 18 & Drudgery associated with farming & 0.60 & 0.31 & -0.17 \\
\hline 19 & Poor water harvesting technologies & 0.56 & -0.02 & -0.21 \\
\hline 20 & Lack of weather forecasting technologies & 0.76 & 0.12 & 0.21 \\
\hline 21 & Lack of functional irrigation scheme & -0.12 & 0.73 & 0.00 \\
\hline 22 & $\begin{array}{l}\text { Lack of and high cost of fertilizers for increased } \\
\text { yield of crops }\end{array}$ & -0.10 & 0.76 & 0.05 \\
\hline 23 & Untimely supply of essential inputs for farming & 0.03 & 0.76 & 0.11 \\
\hline
\end{tabular}

${ }^{*}$ Factor 1 = Lack of improved agricultural technology, Factor 2= Low adaptive capacity, and Factor $3=$ Unsustainable agricultural practices.

Improved agricultural technologies refer to those inputs, practices, techniques, devices, machines etc. which have been properly selected and upgraded to be outstanding in meeting specific needs in agricultural production. It is the application of knowledge and skills necessary to deploy principles, procedures and processes in the production of agricultural goods and services for the benefit of 
humanity and the ecosystems. In the current scenario of climate change, there need to be improvement in all areas of agricultural technology in order to provide effective coping strategies to sustain livelihoods.

Unfortunately, it has been shown that farmers in the area still lack the fundamental technologies to even ensure food security. This is serious because climate change will worsen the farmers' situations. This problem can be attributed to inadequate research and development initiatives in public and private institutions to develop effective technologies to support agricultural production even in the event of climate change. However, it is known that the most important obstacle to the development of technological enterprises in sub-Saharan Africa is not the lack of resources but their isolation (Schmitz, 1995). The isolation of researchers and research and development (R\&D) institutions is cited by many African scholars as one reason for the weak performance in building technological capabilities (Cisse, 1992). This lack of links between the needs of enterprises, communities and the $R \& D$ institutions create a real problem in innovation development and sustainable agricultural production that can withstand climate change events.

Low adaptive capacity refers to the inability of a people to effectively and efficiently cope with the incidences of climate change impacts under a particular condition and time. It places the people at a disadvantage position in terms of harnessing the opportunities and addressing the challenges posed by climate change. Africa's high vulnerability to climate change has been linked to its low adaptive capacity (Ozor, 2009; IPCC, 2007). This is as a result of numerous factors already highlighted in this study but most importantly the lack of income, absence of reliable institutions to provide required capacity to cope, and lack of government support and goodwill (Ozor, 2009).

Article 2 of the United Nations Framework Convention on Climate Change (UNFCCC) requires 'that food production is not threatened'. In assessing the climate change impacts on food production, the adaptive capacity of agricultural systems is of immense importance and is given due consideration (German Advisory Council on Global Change, WGBU, 2003). This capacity differs substantially between regions. Unfortunately, the regions affected most are the ones with the least adaptive capacity - i.e. the developing countries (IPCC, 2001). However, current efforts are directed towards people's vulnerability, livelihood, coping and adaptive capacity and seeks to foster participatory local adaptation to climate change. Adaptation at the community level means being able to maintain (and preferably improve) the current living standards in the face of expected changes in climate trends and the intensity and frequency of severe events that may affect people's livelihoods.

Unsustainable agricultural practices refer to the farming practices which are not recommended in the bid to ensure optimum productivity and sustainability of resources. It includes all the activities undertaken by farmers knowingly or unknowingly that further predispose them to the vulnerability of climate change impacts. The study has revealed that there are many poor and unsustainable agricultural practices being carried out by farmers in the area. For instance, bush burning is a practice which farmers are not yet quick in abandoning for reasons of 
convenience, hunting and energy (firewood). However, this practice has been shown to not only lead to loss of organic matter in the soil and predisposing the soil to erosion, but has contributed to deforestation, emission of greenhouse gases, and loss of lives and property especially when it is not properly controlled. This underscores the need for agricultural extension service as a tool for educating rural people on agricultural best practices and methods required to achieve sustainable production especially in the current event of climate change to step up their service delivery in this direction. Extension can build the requisite capacity of farmers to respond effectively and cope with the incidences of climate change. This will require retraining of personnel to be able to deliver effectively this service, knowing that climate change is a pressing current issue.

\section{A framework for mitigating and adapting to climate change impacts}

Figure 1 shows a framework for mitigating and adapting to climate change impacts in Enugu State. The measures ranged from agronomic best practices to technology development and institutional interventions.

Despite the fact that worldwide farming is a significant source of greenhouse gas emissions, it is impracticable and non equitable to impose all reduction targets on the domain of agriculture leaving off the industries. Agricultural activities when properly harnessed can therefore help a great deal in mitigating the impacts of climate change, apart from ensuring adequate food security. The above framework presents measures that have sustained people in the area and those they perceived will be helpful in coping with climate change challenges. 


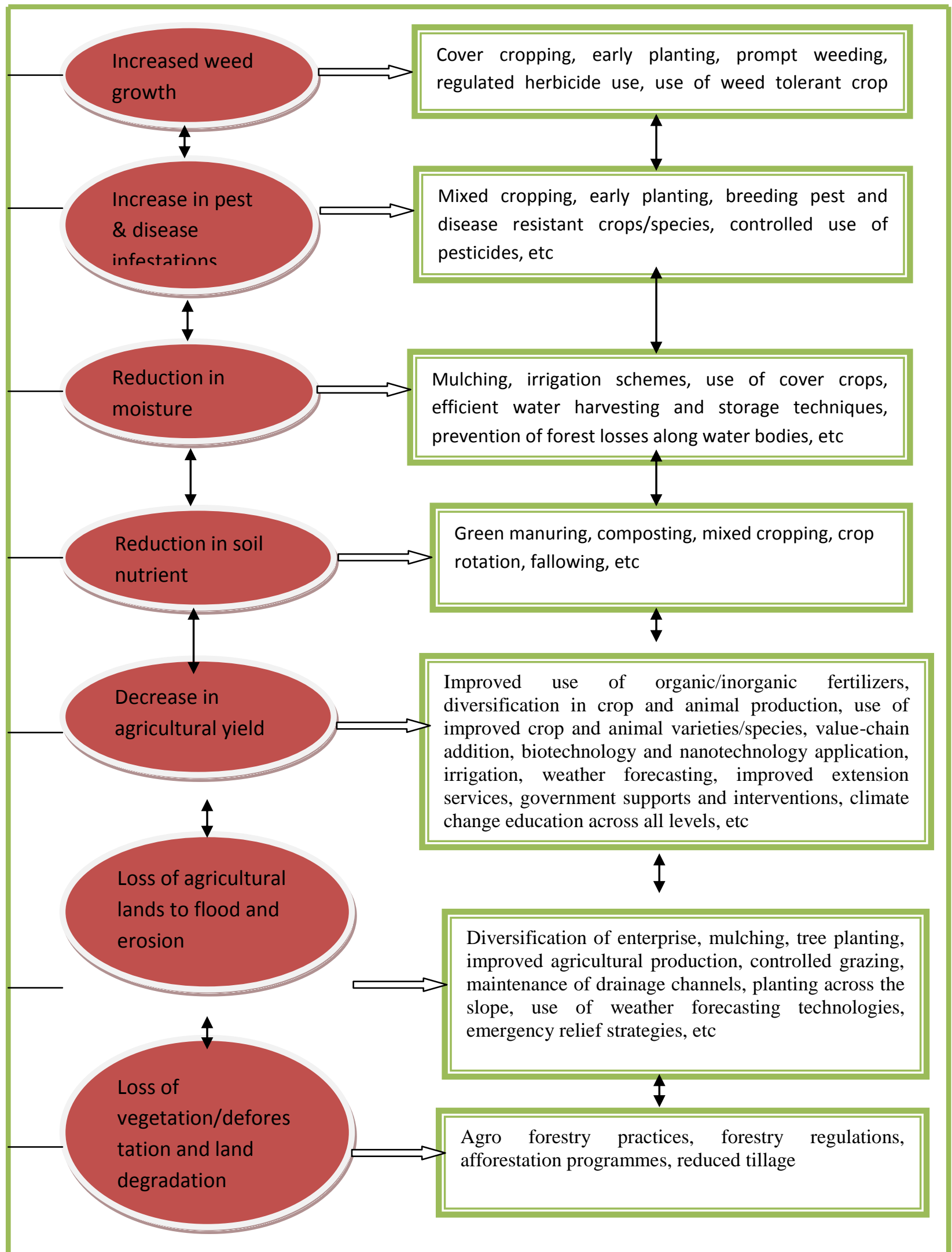

Fig. 1: A Framework for mitigating and adapting to climate change impacts in agriculture 


\section{CONCLUSION AND RECOMMENDATIONS}

The study examined the reasons why farmers find it difficult to adapt to climate change impacts in Enugu State. It also developed a framework for mitigation and adaptation to climate change impacts in the State. Results showed that the major constraints to adaptation in Enugu State were lack of improved agricultural technologies, low adaptive capacities and unsustainable agricultural practices in the area. The study also found out that a mix of agronomic best practices; technological development and institutional interventions were needed for effective adaptation to climate change impacts. The paper recommends effective education and training to build and strengthen the capacity of farmers and people in the area to respond proactively to the impacts of climate change and climate variability. Agricultural extension service therefore has a crucial role to play in informing its clientele (farmers) on how best to adapt to climate change impacts. This will require some further training on the part of the extension personnel in order to build their own capacity to effectively strengthen farmers' capacities.

\section{REFERENCES}

Achike, A. I. (2002) Gender Dynamics of agricultural Technological Change Implication on income Poverty Alleviation in Southeastern Nigeria. A Research Proposal submitted to the Africa Technology Policy Studies (ATPS) Network, Nairobi, Kenya, Presented to the ATPS International Workshop held at Abuja, November 10 - 16, 2002.

Africa Action (2007). Africa Policy e-Journal. Available at http://www.africaaction.org (12/11/07).

African Technology Policy Studies Network (ATPS) and the United Nations Environment Programme (UNEP) facilitated Global Adaptation Network (GAN) (2008) Science, Technology and Climate Change Adaptation in Africa. Proceedings of the ATPS Annual Conference and Workshop held in Johannesburg, South Africa, 19-22 November: 50-60.

Agwu, E A.. and Anyanwu, A. C. (1996). Socio-cultural and Environmental Constraints in Implementing the NALDA Programme in South eastern Nigeria. A case study of Abia and Enugu State. Journal of Agriculture and Education Vol. 2, pp. $68-72$.

Cisse, K. M. (1992). "Managing University-based Research Institutes in Africa: Evaluating the prospects for improvement. Higher Education Policy, 5(2),5560.

Comrey, A. L. (1962) The minimum residual method of factor analysis. Psychological Reports, 11, 15-18.

Consultative Group on International Agricultural Research (CGIAR) (2008). Global Climate Change: Can Agriculture Cope? Available at: http://www.cgiar.org/.8/8/2008. 
Ekwueme, J. N. (2006), Adoption of Improved Agricultural technologies Disseminated via Radio farmer programme by farmers in Enugu State. M.Sc. Project, Department of Agricultural Extension, University of Nigeria, Nsukka.

ENADEP (2007). Enugu State Agricultural Development Programme (ENADEP) Annual Report, 2007. Enugu.

Enugu State Government Official Gazette (1997). Enugu State Official Gazette No. 25.

Ezike, J. O. (1998) Delineation of old and new Enugu State. Bulletin of the Ministry of Works, Lands and Survey, Enugu State.

Food and Agricultural Organization (FAO), (2007) adaptation to climate changes in agriculture, Forestry and Fisheries: Perspective, Framework and priorities Rome. Available at: fao.org/icata/og/inkr.e.htm.13/11/07.

German Advisory Council on Global Change (WBGU) (2003). Climate Protection Strategies for the 21st Century: Kyoto and beyond. Special Report. Berlin, Germany, WBGU: 1.

Igben, M.S. (1988). Farmers Capability Profile in: M. S. Igben (ed). The Nigerian Farmer and Agricultural Institution. An Assessment of NISER Ibadan, Nigeria. Pp. 657 - 92.

Intergovernmental Panel on Climate Change, IPCC Fourth Assessment Report AR4. Climate Change (2007): Impacts, Adaptation and Vulnerability. Contribution of Working Group II to the Fourth Assessment Report of the Intergovernmental Panel on Climate Change. M.L. Parry, O.F. Canziani, J.P. Palutikof, P.J. van der Linden and C.E. Hanson, Eds. Cambridge University Press, Cambridge, UK: 976 pp.

Intergovernmental Panel on Climate Change (IPCC) (2001). Impact, Adaptation and Vulnerability. Contribution of Working Group II of the Intergovernmental Panel on Climate Change to the Third Assessment Report of IPCC. London: Cambridge University Press.

Mapuno P.,Chiwo R.,Mtambanengwe F.,Adjei-NsiahS.,Baijukya F.,Maria R.,MvulaA., and Gilla K., Farmers Perception Leads Experimentation and Learning. (Chavese-J, Hampson K., Salm M.,Schoubroeck F.,Roem W.,Rooijakkers., and Walsum E., (eds).Dealing with climate change. LEISA, 2008. pp. $28-29$.

National Population Commission (NPC) (2006) Official Census Report. Abuja, Nigeria.

Natural Resources Canada, NRC, (2008) Adaptation 101. Available online at http://adaptation.rncan.gc.ca/101/adapt e.php. retrieved on 8 May 2010. 
Ozor, N. (2009) Implications of Climate Change for National Development: The Way Forward. Debating Policy Options for National Development; Enugu Forum Policy Paper 10; African Institute for Applied Economics (AIAE); Enugu, Nigeria: 25-42.

Pittock, A.B. (2005). Climate Change: Turning up the Heat. London: Earthscan: pp.1-23.

Schmitz, H. (1995). Collective Efficiency: Growth Path for Small-Scale Industry", The Journal of Development Studies, 31(4), 529-566.

The Ministry of Environment of the Federal Republic of Nigeria, (2003). Nigeria's First National Communication under the United Nations Framework Convention on climate change. 